\title{
Oil, Natural Gas, and Intrastate Conflict: Does Ownership Matter?
}

\author{
Tim Wegenast \\ University of Konstanz
}

\begin{abstract}
The impact of natural resources on intrastate violence has been increasingly analyzed in the peace and conflict literature. Surprisingly, little quantitative evidence has been gathered on the effects of the resource-ownership structure on internal violence. This article uses a novel data set on oil and natural gas property rights, covering 40 countries during the period 1989-2010. The results of regression analyses employing logit models reveal that the curvilinear effect between hydrocarbon production and civil conflict onset-often found in previous studies-only applies to countries in which oil and gas is extracted by state-owned companies. The findings suggest that only state-controlled hydrocarbon production might entail peace-buying mechanisms such as specific clientelistic practices, patronage networks, welfare policies, and/or coercion. At the same time, it seems that greed and grievance are more pronounced whenever resources lie in the hands of the state. Exploring the within-country variation, further analyses reveal that divergent welfare spending patterns are likely to be one causal channel driving the relationship between resource ownership and internal violence.
\end{abstract}

In recent years, peace and conflict literature has increasingly concentrated on natural resources as a potential source for intrastate conflict. The juxtaposition of "greed" and "grievance" in Collier and Hoeffler's (2004) seminal work, for example, suggests that a resource-related opportunity structure and group-related grievances may explain the onset of internal violence. Territorial, separatist civil wars in Indonesia, Nigeria, and Sudan, as well as governmental conflicts in Angola, Republic of Congo, and Sierra Leone seem to confirm the destabilizing effect of specific natural resources. Oil, gas, and diamonds, in particular, have been found to promote intrastate conflict in various analyses (see Fearon and Laitin 2003; Hegre and Sambanis 2006; Lujala 2010; Ross 2006).

While several resource-rich countries have indeed experienced deadly conflicts, the role of commodities as a promoter of violence is still contested. Le Billon (2010), for example, finds that oil-producing states in Africa have 
not been more susceptible to civil wars than non-oil producers. Some studies maintain that previous findings linking resources to domestic conflict may be a product of spurious correlation. Brunnschweiler and Bulte (2008) and Thies (2010), for example, find no direct link between these two variables. Other authors claim that oil may even be associated with domestic stability and lower levels of violence (Basedau and Lay 2009; Brunnschweiler and Bulte 2009; Smith 2004).

As evidenced, the relationship between certain natural resources and conflict is still ambiguous and poorly understood. Given the range of alternative findings, studies have started to focus more intensely on the specific risks leading to violence within a resource-rich environment (for example, Basedau and Richter 2014; Le Billon 2010). One important explanatory variable, however, has been largely ignored by the present quantitative literature: resource ownership. Although many of the explanations for the resource-conflict nexus rely on ownership patterns, distributional conflicts, and/or rentier-state mechanisms, empirical analyses have drawn exclusively on rough measures of resource abundance or resource dependence without actually accounting for ownership. ${ }^{1}$

By shedding light on the conditions under which resources may promote or prevent internal violence, this article tries to provide more clarity to a research field characterized by contradictory findings. Utilizing a novel data set on oil and gas ownership, it argues that information on who extracts the commodities within a country may advance our understanding on the resource-violence link. It seems plausible to assume that only state-controlled hydrocarbon production may entail peace-buying mechanisms by filling governments' coffers, giving way to clientelistic practices, granting more fiscal autonomy, and reducing the legitimation pressure faced by the state. Through public oil companies, governments may also spend more on coercion or large-scale redistributional policies. At the same time, public oil money may exacerbate political competition for access to the key bodies responsible for managing resource-revenue distribution. By offering selective incentives in the form of future material rewards, it may facilitate the mobilization of insurgents and promote violence.

Employing logit estimations on pooled time-series cross-sectional data, this article tests whether ownership patterns of hydrocarbons-namely whether oil and gas production is controlled by the state or by private companies-affect the potential for conflict within countries. The regression analyses reveal that the curvilinear effect between per capita hydrocarbon production and civil war onset-often found in previous studies-only

\footnotetext{
${ }^{1}$ It is important to note that the state is the sole owner of natural resources such as hydrocarbons or minerals in the great majority of countries worldwide. In this article, the term ownership is used as a synonym for the mode of resource extraction. Therefore, state ownership denotes instances in which natural resources are extracted by state owned companies.
} 
applies to countries in which oil and gas production lies mainly in the hands of the state. A further statistical analysis finds that within-country differences in welfare-spending patterns may partly explain why only state-owned hydrocarbons are associated with an increased-or decreased-conflict potential.

The rest of this article proceeds as follows: The next section reviews the existing literature on the impact of natural resources on domestic stability and internal violence. The article's main argument is presented in the third section, shedding light on how the resource-ownership structure influences the risk of civil war onset. A description of the variables as well as the research design employed in this study is given in the fourth section, which is followed by the article's quantitative findings. The sixth and final section presents the conclusion and highlights areas that require further research.

\section{Review of the research on natural resources, domestic stability, and civil wars}

Influenced by the research of Paul Collier and Anke Hoeffler, a growing body of literature has advanced our knowledge on the relationship between natural resource abundance and conflict propensity. The rent-seeking view of resources as a source of conflict claims that primary commodities may provide rent seekers with both the means and the incentives to fight. According to this view, resource wealth increases the profitability of civil war by raising the prize of capturing the state. Different authors maintain that primary commodities often increase the risk of civil war by providing insurgents with the opportunity to finance large-scale violence and making warfare militarily feasible (Collier and Hoeffler 2004; Le Billon 2001). Resources may also provide the motive to take up arms, given resourcerelated grievances such as forced migration, ecological distress, environmental damage, and the withholding of resource revenue. Costs and benefits related to resource extraction may be the driving forces of conflict (for example, Collier and Hoeffler 2004; Lujala 2010; Ross 2003).

Other authors claim that resources have a more indirect impact on conflict; first, resources may instigate predatory rent-seeking behavior, which simultaneously reduces the quality of institutions' and states' counterinsurgency capacity (Fearon and Laitin 2003; Humphreys 2005). Second, resource production may create economic and social grievances resulting from resource-related terms-of-trade shocks, currency appreciations, and increasing inequalities (Ross 2003, 2004, 2012). ${ }^{2}$

In recent years, the resource-conflict link has increasingly been questioned (see Brunnschweiler and Bulte 2009; Thies 2010). Authors stress the

\footnotetext{
${ }^{2}$ For an overview of the possible mechanisms driving the relationship between natural resources and civil war onset, see Humphreys (2005), Ross (2004, 2006), and Le Billon (2008).
} 
need to examine the precise conditions under which primary commodities act as a catalyst for violence (for example, Basedau and Richter 2014; Collier and Hoeffler 2005; Humphreys 2005). Contextual conditions identified in the literature include the characteristics of the available resource (Ross 2003; Snyder and Bhavnani 2005) or the point in time in which revenues arrive (Humphreys 2005). Le Billon (2001, 2008) stresses the lootability of resources, noting that the exploitation of "diffuse" and "distant" resources like alluvial diamonds, alluvial gold, or drugs cannot be controlled by central governments-thus they are more lootable for rebels (see also Lujala 2010).

Other authors point to the fact that a country's resource abundance and dependence are not identical and have different implications for the risk of civil war (Basedau and Lay 2009; Ross 2006). The sociopolitical environment within resource-abundant countries might also pose specific risks; as shown by some authors, relations between identity groups (Sorens 2011; Wegenast and Basedau 2014) and the institutional framework-such as the electoral system (Wegenast, 2013) - may interact with natural resources and influence the likelihood of conflict.

In contrast to the literature viewing natural resources as a potential source of conflict, the rentier state theory (Luciani 1987; Mahdavy 1970) argues that resource revenues may contribute to intrastate stability by facilitating the implementation of large-scale redistribution policies and thereby pacifying opposition groups. Oil-rich countries are often perceived as distributive states, where governments are mainly concerned with the internal distribution of rents (Karl 1997). High incomes from resources may allow states to employ peace-buying mechanisms such as repression, redistributional policies, low taxation, social benefits, political corruption, or patronage.

Political corruption can foster domestic peace within oil-wealthy countries, where private privilege is offered in exchange for political loyalty and to accommodate the opposition (Fjelde 2009). Arezki and Brückner (2011) argue that in countries with a high share of state participation in oil production, oil rents have a significant effect on corruption, and there is no threat to state stability. In addition to the possibility of buying the consent of key segments of society, large oil rents are often used to increase states' military and counterinsurgency capacities. These rents may provide a readily available pool of funding for military equipment and personnel (Cotet and Tsui 2013; Le Billon and El Kathib 2004). Employing a simultaneous equations framework to address the endogeneity among state capacity, natural resources, and civil war onset, Thies (2010) also questions the conflict-enhancing effect of natural resources. Drawing on predatory theory, the author argues that primary commodities are a natural source of revenue for both rulers and rebels, and when most of the resource wealth accrues to governments' coffers, state capacity may be strengthened. According to this view, states (and not rebels) are the main beneficiary of primary commodity revenue. 
Governments of resource-abundant countries are also not heavily dependent on taxes as a source of state income, meaning citizens may face a lower tax burden (Humphreys 2005). Morrison (2008) finds that nontax revenue such as oil is associated with lower taxation of the elite in democracies, higher social spending in dictatorships, and more regime stability overall. Furthermore, resource rents may be employed to finance social programs and projects, assuring regime legitimacy and citizens' support. Often, resource income is used to distribute material benefits throughout society (for example, Heydemann 2004). According to Herb (2005:297), rich rentier states often use oil rents to create a larger middle class or pay for schoolteachers.

Several authors have tried to reconcile the described conflict-enhancing and peace-buying effects of natural resources by considering the degree of resource dependence or abundance. They show that the relationship between resource wealth and the probability of civil war follows an inverted U-curve: Resources increase the chance of rebellion only up to a certain point. Beyond a critical level of resource rents, an increase in rents reduces the risk of internal violence. Collier and Hoeffler (2004), for example, find that resource dependence (as measured by the ratio of primary exports to GDP) has a curvilinear effect on the onset of civil war (see also Elbadawi and Sambanis 2000). This finding has been corroborated by Basedau and Lay (2009), who also show that high levels of oil abundance (as measured by total per capita oil production) reduce the risk of internal violence. The authors maintain that only high levels of oil wealth enable rulers to buy peace through clientelist networks, large-scale distributional policies, and a large military apparatus. Countries exhibiting lower levels of resource wealth and thus being incapable of buying political legitimacy or military strength are more susceptible to internal violence and insurgency (see also Basedau and Richter 2014).

In a disaggregated, quantitative analysis on the relationship between oil and violence in the Niger Delta, Oyefusi (2007:21) concludes that "while the discovery of oil in a community is likely to trigger violence, the probability of participating in armed conflict reduces as the quantity of oil resources available in the community increases (see also Oyefusi 2010). The quadratic relationship between resources and conflict is also stressed by the formal work of Bjorvatn and Naghavi (2011). The authors' game-theoretic model shows that the risk of conflict is highest "for intermediate levels of resource rents, where the government cannot make credible commitments to the opposition groups" (p. 740).

Relying on the concept of the rentier state, this article lies in the tradition of the studies cited. If natural resources such as oil exert a curvilinear effect on intrastate conflict, this effect should be particularly pronounced when natural resource extraction is controlled directly by the state. On the one hand, oil and gas production through national oil companies (NOCs) 
increase the prize of capturing the state more than when hydrocarbons are extracted by private companies. On the other hand, hydrocarbons lying in the hands of the state may facilitate the provision of private goods to wouldbe rebel factions or the establishment of a large security apparatus, thereby reducing countries' vulnerability to civil war. I show that the effect of oil wealth on civil war onset is indeed largely dependent on the mode of hydrocarbon extraction.

\section{Resource ownership patterns and intrastate conflict}

As is evident from the literature review, several explanations for the resourceconflict nexus-such as the ability to repress, the provision of social benefits and redistributive policies, the motive mechanism, and the enforcement of clientelist rule-assume that large oil reserves serve to fill state coffers. In spite of the apparent pivotal role of resource extraction modes for internal violence onset, it is rather surprising that-most likely due to the lack of appropriate data-studies have failed to include ownership patterns when operationalizing and testing their advocated mechanisms.

Although states such as Angola, Bahrain, China, Canada, Iran, Mexico, Nigeria, Saudi Arabia, Australia, and Russia all exhibit a high level of hydrocarbon production, the degree of state participation in oil and gas extraction differs greatly among these countries. ${ }^{3}$ The empirical reality shows that ownership structures vary greatly both within and across mineral-rich states over time (Luong and Weinthal 2010). It seems reasonable to assume that the conflict-enhancing or stabilizing effects of natural resources partly depend on the extent to which governments effectively control resource extraction within their countries. ${ }^{4}$

This article maintains that only oil and gas production lying in the hands of the state-as opposed to privatized hydrocarbon production-has a direct impact on a country's internal conflict potential. At least two fundamental differences exist between nationalized and privatized resource sectors that may explain a country's risk of experiencing the onset of civil war: the quantity of steady, non-tax government revenue provided by state-owned companies, as well as the opportunity structure for corruption, clientelism, and job patronage inherent to NOCs.

For a given level of oil and gas, governments are likely to gain more revenue when the hydrocarbon production is done through state-owned enterprises instead of privately owned companies. In fact, several authors show that the main motivation behind governments' decision to nationalize

\footnotetext{
${ }^{3}$ While Canadian and Australian oil and gas production lies nearly entirely in private hands, governments in Bahrain, Iran, Mexico, and Saudi Arabia retain total control over hydrocarbon production. The ownership pattern in the four remaining countries is mixed.

${ }^{4}$ Andersen and Ross (2012), for example, demonstrate that peace buying mechanisms associated with hydrocarbon wealth are more likely to produce regime stability when a country's petroleum sector is state owned.
} 
the oil and gas sector is to increase state revenues (see Friedman 2006 or Guriev, Kolotilin, and Sonin 2011). Compared to the taxation of private oil companies, nationalizations are perceived as a better strategy to achieve more state income (Mahdavi 2011:5). Empirical evidence corroborates the claim that public revenues are larger when the hydrocarbon extraction lies in the hands of the state. Andersen and Ross (2012), for example, note that most oil-producing autocracies nationalized their hydrocarbon production in the 1970s and started to collect the rents that previously went to the international oil companies. As a consequence, the size of government revenues grew considerably (see also Ross 2012). According to Mommer (2002), nationalizations raised governments' shares of oil profits from $50 \%$ in the early 1960 s to $98 \%$ by 1974 .

Besides generating more direct income for the state, NOCs may provide an opportunity structure for clientelism, corruption, and cronyism. Various authors have described how NOCs serve as sources of corrupt practices and vehicles to buy political consent in rentier states. Analyzing the oil production in Latin America, Manzano and Monaldi (2008), for example, note that national oil companies such as Mexican PEMEX often become a clientelistic instrument of the ruling party, providing rents that may be used to overemploy and overpay party supporters. McPherson and MacSearraigh (2007) describe how NOCs such as the Nigerian National Petroleum Corporation (NNPC) or Indonesia's Pertamina are misused to buy off political opponents. According to the authors, many NOCs are characterized by a high degree of nontransparency. ${ }^{5}$ Andersen and Ross (2012:12) note that many rulers "used their national oil companies to gain greater control over the distribution of patronage, and to cloak these transactions in secrecy" (see also Stevens 2008). This descriptive evidence is reinforced by quantitative findings. Quinn (2008:84), for example, finds that "majority state ownership of the most important economic sectors of a country results in higher levels of corruption." This finding is corroborated by Arezki and Brückner (2011), who show that oil rents have a positive effect on corruption only in countries with a high share of state participation in oil production.

NOCs are often used to accommodate the political opposition and buy political legitimacy. The lack of transparency allows rulers to use oil rents as a tool for gaining greater control over the distribution of patronage (Ross 2012). State leaders have direct access to the revenues generated by the NOCs and may conceal the actual figures on oil revenue and spending from the public. ${ }^{6}$ In countries such as Azerbaijan and Iraq, more than half of the governments' budgets were funneled through their respective NOCs. Under private ownership

\footnotetext{
${ }^{5}$ The authors note that accounting books are unavailable for a high number of NOCs. Also, many NOCs do not undergo transparent auditing (McPherson and MacSearraigh 2007:210).

${ }^{6}$ The budget of the Iraq National Oil Company, for example, was confidential.
} 
arrangements, nonstate actors are the direct claimants of the revenues generated from hydrocarbon productions. The primary interest of private actors is to maximize the profits on their investments in the oil sector. Generally speaking, private oil firms are more likely to be characterized by well-defined managerial structures, objective criteria to measure company performance, and more transparency (Luong and Weinthal 2010:56).

These two divergent characteristics (that is, the total amount of oil revenues accruing to the state and the degree of transparency and accountability) have implications for the peace-buying and conflict-enhancing mechanisms inherent to resource production. Non-tax revenues over which governments have direct access through NOCs may further the competition for control over the key bodies responsible for managing hydrocarbon rents, thus increasing the risk for conflict among societal groups. The prospect of capturing future oil or gas income may thereby act as a selective incentive that motivates individuals to participate in political or armed conflict. ${ }^{7}$ Hydrocarbon production lying in the hands of private firms may certainly also bring about greedy intentions among different state actors. However, as has been described, private oil companies generate less state income than NOCs. Also, the prospect of amassing individual benefits through corruption or patronage is smaller. ${ }^{8}$

While the large revenues provided by NOCs and the lack of transparency associated with state-controlled resource production may further intrastate conflict, it may at the same time promote internal stability. In line with the quantitative findings cited in the literature review (Basedau and Lay 2009; Collier and Hoeffler 1998; Elbadawi and Sambanis 2000), this article claims that the total amount of oil and gas revenues accruing to state coffers defines whether hydrocarbons have a conflict-enhancing or rather stabilizing effect on countries' domestic politics. In contrast to moderate levels of hydrocarbon income, large petroleum revenues in the hands of the state enable rulers to establish patronage networks and to considerably increase pork-barrel spending.

Rulers of petrostates use corruption in order to offer private privilege in exchange for political loyalty and to accommodate the opposition, thereby ensuring domestic peace (see Fjelde 2009). Rents from oil or gas may also be employed to lower taxes and win "popular acquiescence through distribution" (Anderson 1987:10). ${ }^{9}$ Also, the unlimited and

${ }^{7}$ Ross (2004) highlights the role of so called booty futures in order to finance rebellion in countries such as Liberia, Sierra Leone, and the Republic of Congo.

${ }^{8}$ The option of expropriating private hydrocarbon corporations is often not viable, as expropriation usually comes at a high cost and entails risks (Guriev et al. 2011). Moreover, some countries may simply lack the know how to exploit hydrocarbons through state owned companies.

${ }^{9}$ As outlined in the literature review, Thies (2010) unites the civil war and state building literatures by employing the predictions from predatory theory. The author stresses that governments are the main beneficiaries of natural resource revenue even in the presence of rebels as revenue seeking predators and finds that natural resources may in fact enhance the capacity of the state. 
direct control over the resource sector may allow oil-rich governments to invest in a large repressive apparatus and/or welfare policies. Indeed, some authors show that natural resources such as hydrocarbons may increase social spending and internal stability (Morrison 2008). Welfare spending is found to reduce the probability of civil war onset (Taydas and Peksen 2012), and NOCs, in particular, are believed to support the building of strong welfare states (Marcel and Mitchell 2006). Furthermore, hydrocarbons are often employed when building up a large military apparatus and deploying coercion. As described by Le Billon and El Kathib (2004:110-112), oil rents that are independent of public taxation enable rulers to build up a strong military (see also Cotet and Tsui 2013).

While clientelistic rule, increased welfare spending, or a large military can be found in rentier states with high per capital oil revenues (for example, Luciani 1987; Mahdavy 1970), countries with lower levels of hydrocarbon abundance such as Algeria, Angola, or Nigeria often lack the financial capacity to establish these forms of peace-buying mechanisms (see Basedau and Lay 2009). Thus, it becomes evident that the prevalence and applicability of the conflict-promoting or peace-buying mechanisms inherent to oil-rich states may depend largely on how hydrocarbons are extracted and on the total amount of hydrocarbon revenues. Intermediate levels of state-controlled oil and gas production are expected to increase the risk of civil war onset, while the impact of privately owned hydrocarbons on internal conflict is expected to be only marginal or nonexistent. High levels of state-controlled hydrocarbons, in contrast, are expected to reduce a country's internal violence potential, whereas this conflict-reducing effect is not assumed for countries in which oil and gas are extracted by private actors. By employing a novel and unique data set on hydrocarbon ownership, the next section empirically tests these two hypotheses.

\section{Data and empirical strategy}

\section{A new data set on hydrocarbons' property right structure}

In order to measure the key independent variable, this article relies on our new Oil and Gas Ownership Structure (OGOS) data set. Until recently, the only existing cross-national data set on states' property rights over hydrocarbon production was that developed by Luong and Weinthal (2010). Their work has considerably advanced our understanding of the importance of ownership patterns within the resource curse debate. The authors coded the ownership structure of 50 oil-abundant developing countries based on these countries' "constitutions, official laws and regulations governing the mineral sector, and (where available) mineral contracts" (p. 311). Four discrete categories were drawn up: 
state ownership with control, state ownership without control, private domestic ownership, and private foreign ownership.

Our assessment of countries' ownership structures differs from the one developed by Luong and Weinthal (2010) in several ways; our data include a wider range of countries from the developed and the developing world, focusing both on hydrocarbon abundance and dependence. In addition, our data set also covers oil and gas production, instead of considering only petroleum. The most important difference, however, is that we draw on actual hydrocarbon output figures to measure states' ownership structures, whereas Luong and Weinthal rely exclusively on countries' legislation. Our focus on output figures allows for a more precise and valid operationalization of ownership within the hydrocarbon sector. Coding that relies exclusively on country legislation is more likely to measure the adoption of a certain ownership structure as opposed to its actual implementation. As suggested by Luong and Weinthal (p. 9) themselves, a change in legislation signals the intent to alter the ownership structure but says little about whether such a change was successfully implemented. A final, and rather obvious, advantage of our data is that they provide numerical instead of categorical variables. Compared to Luong and Weinthal's rather static dummy variables, our data are capable of identifying smaller changes within countries' ownership structures over time.

In order to select our sample, we first included all countries that, taken together, accounted for $99 \%$ of the world's total oil and gas production during the period $1989-2010 .{ }^{10}$ In a second step, we selected those countries whose oil and gas exports made up at least $10 \%$ of their total exports on average for the given period. This procedure provided us with 40 hydrocarbon-abundant and/or hydrocarbon-dependent states. ${ }^{11}$ Subsequently, we gathered information on the total production output of all oil and gas production firms within each country for the period under analysis. The main source for this information was Evaluate Energy, a service that provides information on the reported production volume for the majority of publicly quoted oil and gas companies within each state. While this database contains precise output figures for all important privately owned firms, it lacks information on NOCs' hydrocarbon production within some countries for certain time periods. ${ }^{12}$ Thus, we further drew on the information provided by the country reports of the US Geological Survey (USGS) to assess the importance of NOCs-vis-à-vis privately owned firms-within each country and year. ${ }^{13}$ As USGS reports contain estimates of the total market share of

\footnotetext{
${ }^{10}$ Data on oil and gas production come from Evaluate Energy, http://www.evaluateenergy.com/.

${ }^{11} \mathrm{~A}$ list of all countries as well as the respective mean values of their ownership variables is presented in Table A1 in the appendix.

${ }^{12}$ This is mostly owed to the fact that some NOCs do not publicly disclose their exact production figures.

${ }^{13}$ See http://www.usgs.gov/.
} 
many NOCs, we were able to obtain the majority of missing values. ${ }^{14}$ In isolated cases, such as Russia, we further relied on country-specific studies.

Remaining deviations between a country's total reported output and the sum of the production of its individual oil and gas firms has three main causes: nonreporting or underreporting by NOCs, a lack of information on some very small privately owned firms, and the lack of exact participation shares of NOCs within joint ventures or production sharing agreements. ${ }^{15}$ Eight states lack reliable information on the companies operating within the hydrocarbon sectors for several years: Azerbaijan, Bolivia, Equatorial Guinea, Indonesia, Kazakhstan, Libya, Syria, and Vietnam. ${ }^{16}$ For these countries, missing observations for various consecutive years could not be replaced by the information from the USGS.

As a final step, we integrated information about each firm's propertyrights structure, which was taken from Energy Intelligence's Petroleum Intelligence Weekly (PIW). ${ }^{17}$ PIW publishes a compilation of the top 100 hydrocarbon production firms (top 50 for the period 1989-1993) in an annual supplement to its publication. These 100 firms make up the bulk of the world's oil and gas supply with a market share of about $75 \%$ during the sample period. The data set provides information on the exact share of state ownership for each listed firm as well as the respective country of origin. We then matched this information on firms' ownership structures and respective country of origin, with the previously gathered data on firms' output. As PIW includes only the 100 most important companies for each year in its publications, we coded the remaining noncovered companies by accessing their respective Web sites. This allowed us to gather four variables that measure the total amount of hydrocarbons produced by (1) state owned, (2) privately owned, (3) foreign, and (4) domestic companies.

Our final data set covers 40 countries throughout the period 1989-2010. Overall, the data are in line with Luong and Weinthal's (L/W) data set. However, important differences are observable in deviant cases like Algeria, Angola, or Brunei. During the period 2005-2010, L/W classify Algeria's oil industry as "private foreign ownership." Our real production figures, however, reveal that nearly $90 \%$ of total hydrocarbons are produced by state companies. Angola and Brunei are characterized by a public-private ownership structure. Our data indicate that between 1999 and 2010, private firms

\footnotetext{
${ }^{14}$ As an example, approximately $60 \%$ of Nigeria's total oil and gas output was of unknown provenance prior to 2004 (up to 2003, Evaluate Energy only provides production figures of privately owned companies operating within this country). According to the single reports of the US Geological Survey, the market share of Nigeria's NOCs was around $60 \%$ during the given period. Thus, we could attribute the missing production to the state.

${ }^{15}$ For these reasons, the sum of the correspondent shares of state and privately controlled hydrocarbon production do not add up to $100 \%$ in some countries (or add up to more than $100 \%$ in the cases of Brazil, Oman, and Venezuela).

${ }^{16}$ While missing observations are limited to single years in Azerbaijan, Equatorial Guinea, and Libya, the remaining five mentioned countries are marked by missing information for longer time periods.

${ }^{17}$ See http://www.energyintel.com/Pages/EIG GroupHome.aspx.
} 
were responsible for a higher production share than public companies in both countries. However, L/W classify their oil sectors as "state ownership without control" throughout this period. Similar differences can be found for other countries.

\section{Description of variables and estimation strategy}

In order to test both hypotheses outlined in the previous section, the regression analysis relies on the total amount of hydrocarbons (in thousand barrels of oil equivalent per day) ${ }^{18}$ produced by state-owned (state hydrocarbons) or privately owned firms (private hydrocarbons) both in per capita terms and as a share of country GDP. The dependent variable is civil war onset as defined by the UCDP/PRIO Armed Conflict Dataset (Version 4-2012) (see Gleditsch, Wallensteen, Eriksson, Sollenberg, and Strand 2002). The variable civil war onset takes the value of 1 if the threshold of 25 battle-related casualties has been crossed for the first time in the year under consideration and 0 otherwise.

The control variables were chosen in accordance with a sensitivity analysis done by Hegre and Sambanis (2006), who performed specification tests to check the robustness of 88 variables frequently used in the literature to explain civil war. Notwithstanding, a "kitchen sink" models considering any control variable that is expected to have an impact on the dependent variable should be avoided. As outlined by Ray (2003) or Achen (2005), a control variable should be included in the analysis only if it is likely to influence the relationship between the key explanatory variables and the dependent variable. According to the authors, control variables showing an impact on the dependent variable that is complementary to that of the key explanatory factor should not be considered.

One important confounding variable to be considered is regime type. The coercive power of autocratic leaders and the perception of higher expropriation risk may deter private oil companies from investing in autocratic or semidemocratic states. In fact, Brunnschweiler and Valente (2013:21) show that, in autocracies and anocracies, domestic control over oil production is considerably larger than in democracies. As the form of government may also influence the risk of conflict, variables measuring regime type and the democratic quality are included in the regression models. Political instability may also jointly affect the choice over oil control regimes and conflict potential. Therefore, a variable measuring the number of years since the occurrence of an institutional change is included in the subsequent estimations. Oil nationalizations are often promoted with the purpose of increasing countries' total economic income (for example, Mahdavi 2011). At the same

\footnotetext{
${ }^{18}$ When calculating the unit "barrels of oil equivalent" (boe), the output of natural gas is standardized according to the energy content of one oil barrel.
} 
time, economic income is an important predictor of intrastate violence and should hence be considered as another relevant confounding variable. The remaining control variables are: log of population size, economic growth and ethnic fractionalization. ${ }^{19}$ All independent variables were lagged by one year in order to counter possible reverse causality.

The risk of internal conflict onset is estimated using logit models for 40 countries throughout the period 1989-2010 using standard errors clustered around countries. ${ }^{20}$ Including only hydrocarbon-abundant (or hydrocarbondependent) states in the sample has the advantage of reducing the risk of structural instability and omitted variable bias. ${ }^{21}$ To minimize the problems of temporal dependence on a history of conflict, a variable reflecting the duration of time since the last event/onset (peace) as well as three natural cubic splines were included in all models, following the recommendation made by Beck, Katz, and Tucker (1998). Additionally, rare-event logit models, as suggested by King and Zeng (2001), were estimated. These authors demonstrate that when binary dependent variables measure the occurrence of rare events, standard logit or probit estimations may produce biased coefficients.

\section{Empirical findings}

The first performed regression analysis tries to replicate the findings of Collier and Hoeffler (1998) and Basedau and Lay (2009), by using the outlined sample of 40 hydrocarbon-producing states. ${ }^{22}$ It does not differentiate between ownership types but rather assesses the impact of total oil and gas production (both in per capita terms and as a share of total exports) on civil war onset. Given the strong empirical evidence for a nonlinear effect between hydrocarbons and conflict outlined in the literature review, a squared term of oil and gas production was introduced in the models.

Table 1 shows that the results are largely in line with those reported in previous studies. Hydrocarbon dependence (measured by total oil and gas production divided by the GDP), increases the risk of violence onset at intermediate levels while reducing the risk after a certain production output has been reached (see Model 2). However, as shown by Brunnschweiler and Bulte (2009), these results might suffer from reversed causality bias and

\footnotetext{
${ }^{19}$ See Table A2 in the appendix for further information on the definitions and sources for all the variables employed.

${ }^{20}$ The period of analysis reflects the availability of the Evaluate Energy data on companies' oil and gas production. Since the coding of countries' oil and gas production patterns is very time intensive, and generating a data set encompassing all hydrocarbon producing states worldwide was beyond the scope of our research project, we had to limit the analysis to 40 countries by applying strict selection criteria described earlier.

${ }^{21}$ Resource wealthy countries share common characteristics that might be relevant for explaining internal violence onset but often remain unobserved, thus creating spurious relationships.

${ }^{22}$ Only country years in which the sum of state owned and privately owned oil and gas figures made up for more than $60 \%$ of the officially reported total hydrocarbon production were considered.
} 
Table 1. Total Hydrocarbon Production and Civil War.

\begin{tabular}{|c|c|c|}
\hline & (1) Civil War Onset & (2) Civil War Onset \\
\hline Peace years & $0.676(0.533)$ & $0.615(0.586)$ \\
\hline pc total production $(\mathrm{t}-1)$ & $58.62^{* *}(26.79)$ & \\
\hline pc total production squared ${ }_{(\mathrm{t}-1)}$ & $275.4(182.2)$ & \\
\hline gdp total production $_{(\mathrm{t}-1)}$ & & $83.83^{* *}(32.54)$ \\
\hline gdp total production squared ${ }_{(\mathrm{t}-1)}$ & & $891.4^{* *}(402.1)$ \\
\hline Mixed regime $_{(\mathrm{t}-1)}$ & $0.305(0.449)$ & $0.641(0.425)$ \\
\hline Instability $_{(t-1)}$ & $0.432(0.350)$ & $0.199(0.363)$ \\
\hline $\mathrm{GDPPC}_{(\mathrm{t}-1)}$ & $0.000192^{* * *}(0.0000733)$ & $0.0000887^{*}(0.0000530)$ \\
\hline (log)population $_{(\mathrm{t}-1)}$ & $0.445^{* *}(0.197)$ & $0.425^{* *}(0.175)$ \\
\hline Growth $_{(\mathrm{t}-1)}$ & $0.0762^{* * * * *}(0.0209)$ & $0.0763^{* * *}(0.0253)$ \\
\hline Fractionalization $_{(\mathrm{t}-1)}$ & $1.807(1.245)$ & $1.160(1.010)$ \\
\hline Constant & $9.253^{* * * * *}(* 2.555)$ & $8.202^{* * * * *}(2.278)$ \\
\hline$N$ & 589 & 589 \\
\hline Prob $>\mathrm{Chi}^{2}$ & 0.0000 & 0.0000 \\
\hline Pseudo $R^{2}$ & 0.287 & 0.246 \\
\hline
\end{tabular}

Note. Logit models using standard errors clustered around countries (shown in parentheses) with onset of civil wars as dependent variable. We account for duration dependence using peace-years correction and three natural cubic splines (not displayed in the table) calculated with the program BTSCS Data Analysis Utility Version 4.0.4.

${ }^{*} p<.10 ;{ }^{* *} p<.05 ;{ }^{* *} p<.01 ;{ }^{* * * *} p<.001$.

should therefore be interpreted with care. Concerning the impact of hydrocarbon wealth (measured by total per capita oil and gas output) on civil war onset, the analysis also indicates an inverted U-shaped relationship; although high levels of hydrocarbon wealth (as captured by the squared term) are only statistically significant at the $11 \%$ level (see Model 1 ). All control variables exhibit the expected signs, with three of them reaching statistical significance at conventional levels: per capita GDP and growth reduce the likelihood of civil wars, while population size is associated with an increased risk of internal violence onset.

After partially corroborating the findings of previous studies, the next regression analysis assesses the importance of hydrocarbon ownership structures as a determinant of intrastate violence. Table 2 summarizes the effects of state and privately controlled hydrocarbon production on civil war onset. Models 1 and 2 confirm that the mode of extraction matters for explaining civil war onset. Per capita state-controlled extraction affects internal violence as hypothesized: Intermediate levels of state-owned oil and gas production increase the potential for conflict, while high levels have a peace-buying effect (both in the baseline model as well as in the extended model containing the relevant control variables). ${ }^{23}$

Figure 1 graphs the relationship between per-capita public hydrocarbon production and civil war onset holding all remaining variables at their

\footnotetext{
${ }^{23}$ The turning point after which state hydrocarbon production reduces the risk of intrastate conflict lies at approximately 90 daily barrels of oil equivalent per capita. The following 15 countries cross this threshold at least once during the period under analysis: Algeria, Bahrain, Brunei, Iraq, Kuwait, Libya, Norway, Oman, Qatar, Russia, Saudi Arabia, Trinidad and Tobago, Turkmenistan, United Arab Emirates, and Venezuela.
} 
Table 2. State and Private Hydrocarbon Production (per Capita and as Share of GDP) and Civil War Onset.

\begin{tabular}{|c|c|c|c|c|}
\hline & $\begin{array}{l}\text { (1) Civil War } \\
\text { Onset }\end{array}$ & $\begin{array}{l}\text { (2) Civil War } \\
\text { Onset }\end{array}$ & $\begin{array}{l}\text { (3) Civil War } \\
\text { Onset }\end{array}$ & $\begin{array}{l}\text { (4) Civil War } \\
\text { Onset }\end{array}$ \\
\hline Peace years & $\begin{array}{c}0.989 \\
(0.705)\end{array}$ & $\begin{array}{c}0.741 \\
(0.609)\end{array}$ & $\begin{array}{c}0.749 \\
(0.744)\end{array}$ & $\begin{array}{l}0.605 \\
(0.713)\end{array}$ \\
\hline pc priv $\operatorname{prod}_{(\mathrm{t}-1)}$ & $\begin{array}{l}35.47 \\
(24.67)\end{array}$ & $\begin{array}{c}23.39 \\
(20.31)\end{array}$ & & \\
\hline pc priv prod squared $(\mathrm{t}-1)$ & $\begin{array}{r}358.6 \\
(246.2)\end{array}$ & $\begin{array}{r}182.0 \\
(146.0)\end{array}$ & & \\
\hline pc gov $\operatorname{prod}_{(t-1)}$ & $\begin{array}{l}51.47^{* * * * *} \\
(13.21)\end{array}$ & $\begin{array}{c}71.24^{* * *} \\
(23.39)\end{array}$ & & \\
\hline pc gov prod squared ${ }_{(t-1)}$ & $\begin{array}{l}312.0^{* * * * * *} \\
(87.97)\end{array}$ & $\begin{array}{l}420.5^{* * *} \\
(155.2)\end{array}$ & & \\
\hline $\operatorname{gdp}$ priv $\operatorname{prod}_{(\mathrm{t}-1)}$ & & & $\begin{array}{c}0.318 \\
(31.48)\end{array}$ & $\begin{array}{c}1.195 \\
(65.67)\end{array}$ \\
\hline gdp priv prod squared $(t-1)$ & & & $\begin{array}{c}300.6 \\
(336.6)\end{array}$ & $\begin{array}{l}650.2 \\
(903.5)\end{array}$ \\
\hline $\operatorname{gdp} \operatorname{gov} \operatorname{prod}_{(\mathrm{t}-1)}$ & & & $\begin{array}{c}294.6^{* * *} \\
(91.04)\end{array}$ & $\begin{array}{c}378.5^{* * *} \\
(140.4)\end{array}$ \\
\hline $\operatorname{gdp}_{\text {gov }}$ prod squared $(\mathrm{t}-1)$ & & & $\begin{array}{l}9685.0^{* * * * * *} \\
(2817.7)\end{array}$ & $\begin{array}{l}11033.0^{* * *} \\
(3912.1)\end{array}$ \\
\hline mixed regime $_{(t-1)}$ & & $\begin{array}{c}0.641 \\
(0.550)\end{array}$ & & $\begin{array}{c}0.534 \\
(0.500)\end{array}$ \\
\hline instability $_{(t-1)}$ & & $\begin{array}{r}0.642 \\
(0.406)\end{array}$ & & $\begin{array}{l}0.740^{* *} \\
(0.313)\end{array}$ \\
\hline $\operatorname{gdpp} c_{(t-1)}$ & & $\begin{array}{c}0.000227^{*} \\
(0.000126)\end{array}$ & & $\begin{array}{l}0.0000922^{* *} \\
(0.0000463)\end{array}$ \\
\hline${ }^{(l o g) p o p u l a t i o n}(\mathrm{t}-1)$ & & $\begin{array}{l}0.215 \\
(0.201)\end{array}$ & & $\begin{array}{l}0.310 \\
(0.238)\end{array}$ \\
\hline $\operatorname{growth}_{(\mathrm{t}-1)}$ & & $\begin{array}{l}0.0767^{* * *} \\
(0.0283)\end{array}$ & & $\begin{array}{l}0.0773^{* * *} \\
(0.0298)\end{array}$ \\
\hline fractionalization $_{(t-1)}$ & & $\begin{array}{c}1.325 \\
(1.096)\end{array}$ & & $\begin{array}{c}0.0754 \\
(0.874)\end{array}$ \\
\hline constant & $\begin{array}{l}3.927^{* * * * * *} \\
(0.810)\end{array}$ & $\begin{array}{l}6.416^{* * * * *} \\
(1.813)\end{array}$ & & $\begin{array}{l}7.424^{* *} \\
(3.041)\end{array}$ \\
\hline$N$ & 635 & 451 & 629 & 451 \\
\hline $\begin{array}{l}\text { Prob }>\mathrm{Chi}^{2} \\
\text { pseudo } R^{2}\end{array}$ & $\begin{array}{c}0.0000 \\
0.276\end{array}$ & $\begin{array}{c}0.0000 \\
0.308\end{array}$ & $\begin{array}{c}0.0000 \\
0.230\end{array}$ & $\begin{array}{c}0.0000 \\
0.301\end{array}$ \\
\hline
\end{tabular}

Note. Logit models using standard errors clustered around countries (shown in parentheses) with onset of civil wars as dependent variable. We account for duration dependence using peace-years correction and three natural cubic splines (not displayed in the table) calculated with the program BTSCS Data Analysis Utility Version 4.0.4.

${ }^{*} p<.10 ;{ }^{* *} p<.05,{ }^{* * *} p<.01 ;{ }^{* * * *} p<.001$.

median values. As evident, the risk of intrastate conflict is on average $10 \%$ higher for country-years with levels of state-controlled hydrocarbon production around 90 daily barrels compared to country-years showing high levels (above 190 daily barrels) or no publicly controlled hydrocarbon production at all. Standardized regression coefficients show that the effect size of stateowned hydrocarbons on civil war onset is substantive: The coefficient size for per capita state hydrocarbons is the largest within the whole model, while the effect size of its squared term is considerably smaller. In contrast, privately 


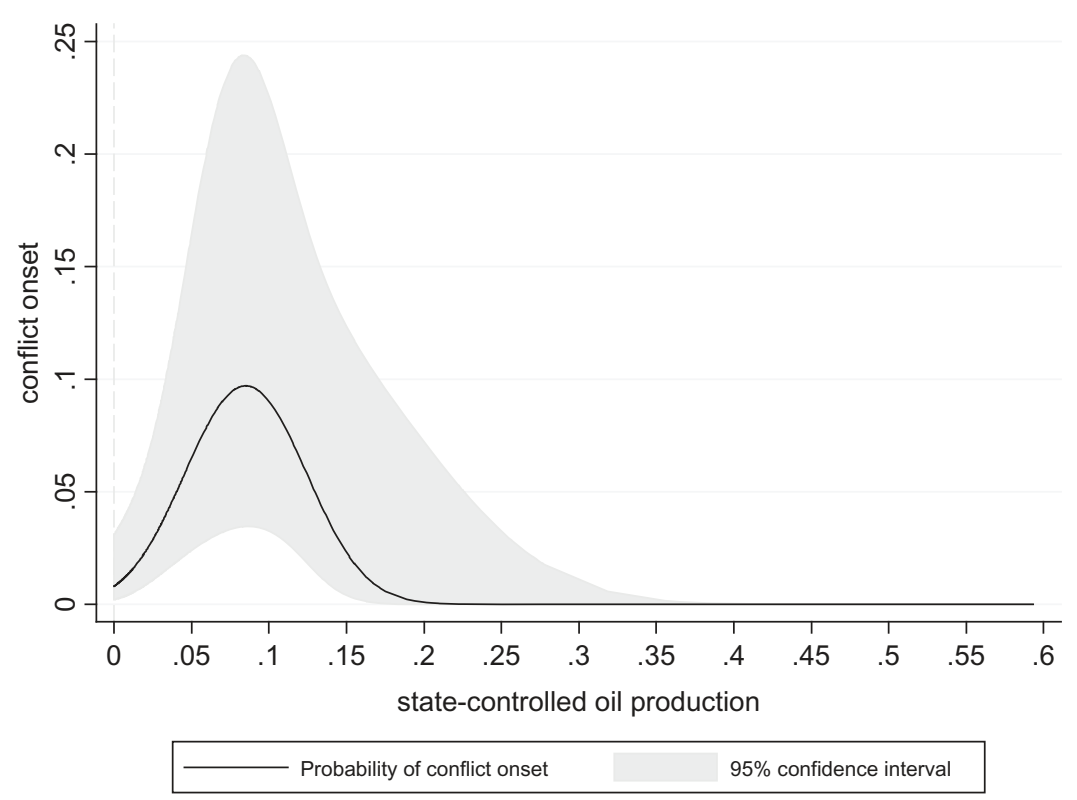

Figure 1. Per capita state-controlled hydrocarbon production and civil war onset.

controlled hydrocarbons show no significant effect on the risk of intrastate violence. A similar conclusion can be reached when hydrocarbon wealth is replaced by hydrocarbon dependence. As evident from Models 3 and 4, state hydrocarbons as a share of GDP exert a curvilinear effect, while private hydrocarbons have no impact on the outbreak of civil wars.

Several robustness checks were performed. All presented models were reestimated using rare-event logit methods and the results were nearly identical. ${ }^{24}$ The reported findings also proved to be robust to the inclusion or exclusion of different sets of independent variables. All models were reestimated, including additional institutional indicators such as regime type or the level of democracy (as measured by Freedom House or Polity2) in order to address possible omitted-variable bias. In particular, two measures of governance quality were added to the estimations: the indicator of Quality of Government compiled by the Political Risk Service Group and the indicator of Government Effectiveness provided by the Worldwide Governance Indicators.

Given the limited number of countries in the sample, the obtained results might be driven by single outliers. Therefore, estimations were recalculated without countries with a high leverage on the regression line. ${ }^{25}$ In addition, regressions were rerun without Angola and Iran, as they account for around $39 \%$ of civil war onsets in the given period. Since Qatar, Kuwait, United Arab Emirates, and Saudi Arabia exhibit very large amounts of state-controlled

\footnotetext{
${ }^{24} \mathrm{All}$ the results from the robustness checks reported are available upon request.

${ }^{25}$ Countries with a high leverage on the results are Azerbaijan, Venezuela, Egypt, Nigeria, and Congo.
} 
hydrocarbon production per capita, these four countries were also simultaneously excluded from the estimations. The article's findings proved to be robust to all of these robustness checks. Likelihood Ratio Tests of the reported specification against several different nested models revealed that the applied full model had a proper specification. Furthermore, a stepwise inclusion of all independent variables indicated that the reported findings are unlikely to be driven by multicollinearity. This was confirmed by an analysis of the predictors' variance inflation factor.

The empirical analysis provides positive evidence for the hypothesized relationship between hydrocarbon's ownership structure and internal conflict onset. Unfortunately, a more detailed test of each of the presented causal mechanisms lies beyond the scope of this article and should be addressed by future research. However, given the strong findings linking resource production with social spending (for example, Morrison 2008) as well as welfare spending and intrastate conflict onset (for example, Taydas and Peksen 2012), it seems worthwhile to analyze whether differences in welfare spending patterns between diverging ownership structures may partially explain the findings reported earlier.

\section{Resource ownership patterns and welfare spending}

The next analysis explores whether the percentage of total hydrocarbons produced by either public or private companies is associated with changing levels of welfare spending. For this purpose, welfare spending (accounting for the three key areas of education, health, and social security) as a percentage of GDP is used as the dependent variable. ${ }^{26}$ Again, the main independent variables of interest is the total amount of hydrocarbons produced by either state-owned or privately owned firms in per capita terms.

Several control variables that are commonly found in the literature (see, for example, Ha 2008; Rudra and Haggard 2005) and are expected to affect the relationship between the key explanatory factor and the dependent variable were considered. To account for income effects and Wagner's Law, GDP per capita (purchasing power parity [PPP] converted from the Penn World Table) was included in the models. Since economic growth may have a countercyclical effect on spending (for example, Burgoon 2001) and, at the same time, may raise the revenue base of the welfare state, this variable was also included. ${ }^{27}$ Trade openness (measured by the sum of total exports and imports divided by the GDP in constant prices) was considered in order to address previous findings of the so-called compensation theory (see Rodrik 1997). ${ }^{28}$ Furthermore, I controlled for election years with a dummy that is

\footnotetext{
${ }^{26}$ These data were taken from Taydas and Peksen (2012).

${ }^{27}$ Growth is measured by the annual growth of GDP taken from World Development Indicators.

${ }^{28}$ Source: Penn World Tables (Heston, Summers, and Aten 2009).
} 
coded as 1 when there has been a legislative or executive election in the given year and 0 otherwise. ${ }^{29}$ To control for the potential effect of partisan politics on welfare spending, a dummy variable indicating when a left-wing party was the largest government party was included. ${ }^{30}$ Finally, since government leaders may overcompensate for inflation under sociopolitical pressure (see Ha 2008:795), the total inflation rate (taken from the World Development Indicators) was equally considered as a control variable.

Given that private and public hydrocarbon production, as well as welfare spending patterns differ considerably within countries for the period under analysis, I used fixed-effects in order to estimate the effects of varying ownership structures on public expenditures. As the research question is primarily longitudinal in nature, exploring the variance of welfare spending within countries over time appears particularly pertinent (see Jackman 1985). By using fixed-effects estimators, differences between countries that drive welfare spending such as countries' economic, political, or cultural institutions as well as different starting points can be better accounted for. In the absence of plausible empirical evidence for the random effects assumption, bias and consistency criteria favor a fixed-effects model. ${ }^{31}$ In addition, theoretical considerations strongly support the use of a within-country estimator because it predicts how changes within countries affect changes in welfare expenditure.

Table 3 shows the estimation results for the period $1989-2005 .^{32}$ As evident, state production of oil and gas exerts a curvilinear effect on welfare spending. While per capita government hydrocarbon production has a negative effect on social expenditure, its squared term is associated with more welfare spending. Thus, from a within-country perspective, substantial levels of state-owned hydrocarbon production seem to drive governments to invest more in social policies such as health, education, or social security, while marginal levels induce state leaders to neglect these types of policies. Private hydrocarbon exploration, in contrast, shows no statistically significant impact on welfare spending. ${ }^{33}$ Very similar results are achieved when changes of hydrocarbon production are used instead of levels as a robustness check. ${ }^{34}$ The outlined results reinforce the assumption that large amounts of state-owned oil and gas entail peace-buying effects as a result of increased social spending. By

\footnotetext{
${ }^{29}$ Source: Database of Political Institutions (DPI).

${ }^{30}$ Source: Database of Political Institutions (DPI).

${ }^{31}$ As noted by Halaby (2004:511), the random effect estimator is strongly influenced by cross sectional variance and underlies the assumption that unobserved heterogeneity is mean independent from the causal variable.

${ }^{32}$ The choice of this time period was contingent on the availability of the welfare spending data from Taydas and Peksen (2012).

${ }^{33}$ Regarding the control variables, per capita GDP is negatively associated with welfare spending, which is in line with previous findings (Ha 2008; Rudra and Haggard 2005). Also, higher inflation increases social expenditures, suggesting that under sociopolitical pressure state leaders overcompensate for inflation. Economic growth also seems to encourage welfare expenditures. All other control variables remain nonsignificant.

${ }^{34}$ These results are available upon request.
} 
Table 3. Per Capita State and Private Hydrocarbon Production and Welfare Spending.

\begin{tabular}{|c|c|c|}
\hline & (1) Welfare Spending & (2) Welfare Spending \\
\hline pc priv $\operatorname{prod}_{(\mathrm{t}-1)}$ & $2.445(11.47)$ & $7.708(11.37)$ \\
\hline pc priv prod squared $d_{(t-1)}$ & $7.959(21.89)$ & $26.53(22.58)$ \\
\hline pc gov $\operatorname{prod}_{(\mathrm{t}-1)}$ & $20.82^{* * * * * *}(3.332)$ & $24.86^{* * * * * *}(5.198)$ \\
\hline pc gov prod squared $\mathrm{d}_{(\mathrm{t}-1)}$ & $7.042^{* * * * *}(1.533)$ & $13.13^{* * * * *}(2.526)$ \\
\hline per capita $\mathrm{gdp}_{(\mathrm{t}-1)}$ & & $0.000322^{* * * * * *}(0.0000677)$ \\
\hline growth $_{(t-1)}$ & & $0.0422^{* *}(0.0177)$ \\
\hline elections $_{(t-1)}$ & & $0.184(0.282)$ \\
\hline inflation $_{(t-1)}$ & & $0.000723^{* *}(0.000321)$ \\
\hline left party $(t-1)$ & & $0.364(0.432)$ \\
\hline trade openness $(\mathrm{t}-1)$ & & $0.00350(0.00739)$ \\
\hline cons & $11.07^{* * * * *}(0.700)$ & $12.67^{* * * * *}(1.245)$ \\
\hline$N$ & 489 & 451 \\
\hline Prob $>F$ & 0.0000 & 0.0000 \\
\hline
\end{tabular}

Note. Fixed Effects Models using year dummies (not displayed in the table) with welfare spending (health, education, and social security). Standard errors in parentheses.

${ }^{*} p<.10 ;{ }^{* *} p<.05,{ }^{* * *} p<.01 ;{ }^{* * * *} p<.001$.

implementing broad welfare policies, state leaders may buy political legitimacy and internal stability.

\section{Conclusions}

This article argued that the oil and gas property-rights structure is an important factor when predicting civil war onset. Compared to privately controlled hydrocarbon production, NOCs provide governments with more state income. Furthermore, NOCs are generally characterized by less transparency and accountability. On the one hand, these properties inherent to state-owned firms may further greed and intensify competition for control over the key bodies that control oil and gas revenues, thereby increasing the risk of internal violence.

On the other hand, large hydrocarbon revenues lying in state hands may allow governments to establish networks of clientelism and patronage, use pork-barrel spending, reduce citizens' tax burden, increase welfare spending, and/or build up a large repressive apparatus. This way, state leaders may co-opt political dissidents, accommodate the opposition, offer private privilege in exchange for political support, and/or exert coercion, thereby securing stability and domestic peace.

The results of the logistic regressions confirm the importance of resourceownership structures as a predictor variable for civil war onset. At intermediate levels, state-controlled oil and gas production fosters internal violence, while reducing the likelihood of conflict at high levels. In contrast, oil and gas production lying in private hands do not affect the risk of intrastate violence. These findings proved to be robust to various operationalizations, model specifications, and statistical estimations. Furthermore, within-country estimations showed that high levels of state-controlled hydrocarbons are associated with more welfare spending. Thus, it seems that different welfare 
spending patterns can partially explain the effect of the resource-ownership structure on intrastate conflict onset.

Much room remains for future research. The intention of this article was to gather initial statistical evidence for the link between resource propertyrights structures and intrastate conflict. Although it provided various explanations for the significant effect of NOCs on civil war onset and investigated one particular channel (welfare spending) in greater detail, it did not perform comprehensive tests for each potential causal mechanism underlying the relationship. Future studies should more carefully explore the precise channels through which state-owned resources may affect countries' conflict potential. In addition, it seems worthwhile to investigate how the propertyrights structures of other resources such as diamonds or gold impact countries' risks of experiencing internal conflicts.

\section{Acknowledgments}

I thank three anonymous reviewers for comments and suggestions to a previous version of this paper. Constantin Ruhe, Laura Albarracin, and Maik Maerten provided outstanding research assistance.

\section{Funding}

Financial support from the German Research Foundation (DFG), as part of the research project Governing the Resource Conflict Nexus, is gratefully acknowledged.

\section{References}

Achen, Christopher. (2005) Let's Put Garbage Can Regressions and Garbage Can Probits Where They Belong. Conflict Management and Peace Science 22(4):327 339.

Andersen, Jørgen J., and Michael Ross. (2012) The Big Oil Change: A Closer Look at the Haber Menaldo Analysis. Unpublished manuscript. Available at http://www.sscnet. ucla.edu/polisci/faculty/ross/The\%20Big\%20Oil\%20Change\%20 \%20APSA\%20version. pdf.

Anderson, Lisa. (1987) The State in the Middle East and North Africa. Comparative Politics 20(1):1 18 .

Arezki, Rabah, and Markus Brückner. (2011) Oil Rents, Corruption and State Stability: Evidence from Panel Data Regression. European Economic Review 55(7):955 963.

Basedau, Matthias, and Jann Lay. (2009) Resource Curse or Rentier Peace? The Ambiguous Effects of Oil Wealth and Oil Dependence on Violent Conflict. Journal of Peace Research 46(6):757 776.

Basedau, Matthias, and Thomas Richter. (2014) Why Do Some Oil Exporters Experience Civil War but Others Do Not? Investigating the Conditional Effects of Oil. European Political Science Review 6(4):549 574.

Beck, Nathaniel, Jonathan N. Katz, and Richard Tucker. (1998) Taking Time Seriously: Time Series Cross Section Analysis with a Binary Dependent Variable. American Journal of Political Science 42(4):1260 1288. 
Bjovertn, Kjetil, and Alireza Naghavi. (2011) Rent seeking and regime stability in rentier states. European Journal of Political Economy 27:740 748.

Brunnschweiler, Christa, and Erwin Bulte. (2008) Linking Natural Resources to Small Growth and More Conflict. Science 320(5876):616 617.

Brunnschweiler, Christa, and Erwin Bulte. (2009) Natural Resources and Violent Conflict: Resource Abundance, Dependence and the Onset of Civil Wars. Oxford Economic Papers 61(4):651 674.

Brunnschweiler, Christa, and Simone Valente. (2013) Property Rights, Oil and Income Levels: Over a Century of Evidence. MPRA Paper No. 52203.

Burgoon, Brian. (2001) Globalization and Welfare Compensation: Disentangling the Ties That Bind. International Organization 55(3):395 413.

Cederman, Lars Erik, Brian Min, and Andreas Wimmer. (2010) Why Do Ethnic Groups Rebel? New Data and Analysis. World Politics 62(1):87 119.

Collier, Paul, and Anke Hoeffler. (1998) On economic causes of civil war. Oxford Economic Papers 50(4):563 573.

Collier, Paul, and Anke Hoeffler. (2004) Greed and Grievance in Civil War. Oxford Economic Papers 56(4):563 595.

Collier, Paul, and Anke Hoeffler. (2005) Resource Rents, Governance, and Conflict. Journal of Conflict Resolution 49(4):625 633.

Cotet, Anca M., and Kevin K. Tsui. (2013) Oil and Conflict: What Does the Cross Country Evidence Really Show? American Economic Journal: Macroeconomics 5(1):49 80.

Elbadawi, Ibrahim, and Nicholas Sambanis. (2000) Why Are There So Many Civil Wars in Africa? Understanding and Preventing Violent Conflict. Journal of African Economics 9 (3):244 269.

Fearon, James D., and David D. Laitin. (2003) Ethnicity, Insurgency, and Civil War. American Political Science Review 97:75 90.

Fjelde, Hanne. (2009) Buying Peace? Oil Wealth, Corruption and Civil War 19851999. Journal of Peace Research 46(2):199 218.

Friedman, Thomas. (2006) The First Law of Petropolitics. Foreign Policy 154:28 36.

Gleditsch, Nils P., Peter Wallensteen, Mikael Eriksson, Margareta Sollenberg, and Havard Strand. (2002) Armed Conflict 1946 2001: A New Dataset. Journal of Peace Research 39 (5):615 637.

Guriev, Sergei, Anton Kolotilin, and Konstantin Sonin. (2011) Determinants of Nationalization in the Oil Sector: A Theory and Evidence from Panel Data. The Journal of Law, Economics and Organization 27(2):301 323.

Ha, Eunyoung. (2008) Globalization, Veto Players, and Welfare Spending. Comparative Political Studies 41(6):783 813.

Halaby, Charles N. (2004) Panel Models in Sociological Research: Theory into Practice. Annual Review of Sociology 30:507 544.

Hegre, Håvard, and Nicholas Sambanis. (2006) Sensitivity Analysis of Empirical Results on Civil War Onset. Journal of Conflict Resolution 50(4):508 535.

Herb, Michael. (2005) No Representation without Taxation? Rents, Development, and Democracy. Comparative Politics 37(3):297 316.

Heston, Alan, Robert Summers, and Bettina Aten. (2009) Penn World Table Version 6.3, Center for International Comparisons of Production, Income and Prices, University of Pennsylvania.

Heydemann, Steven. (2004) Networks of Privilege: The Politics of Economic Reform in the Middle East. New York: Palgrave St. Martin's Press.

Humphreys, Macartan. (2005) Natural Resources, Conflict and Conflict Resolution. Journal of Conflict Resolution 49(4):508 537. 
Jackman, Robert. (1985) Cross National Statistical Research and the Study of Comparative Politics. American Journal of Political Science 29(1):161 182.

Karl, Terry L. (1997) The Paradox of Plenty: Oil Booms and Petro States. Berkeley: University of California Press.

King, Gary, and Langche Zeng. (2001) Logistic Regression in Rare Events Data. Political Analysis 9:137 163.

Le Billon, Philippe. (2001) Angola's Political Economy of War: The Role of Oil and Diamonds, 1975 2000. African Affairs 100(398):55 80.

Le Billon, Philippe. (2008) Diamond Wars? Conflict Diamonds and Geographies of Resource Wars. Annals of the Association of American Geographers 98(2):345 372.

Le Billon, Philippe. (2010) Oil and Armed Conflicts in Africa. African Geographical Review 29 (1):63 90 .

Le Billon, Philippe, and Fouad El Kathib. (2004) From Free Oil to "Freedom Oil": Terrorism, War and US Geopolitics in the Persian Gulf. Geopolitics 9(1):109 137.

Luciani, Giacomo. (1987) Allocation vs. Production State. In The Rentier State, edited by H. Beblawi and G. Luciani. London: Croom Helm.

Lujala, Päivi. (2010) The Spoils of Nature: Armed Civil Conflict and Rebel Access to Natural Resource. Journal of Peace Research 47(1):15 28.

Luong, Pauline, and Erika Weinthal. (2010) Oil Is Not a Curse: Ownership Structure and Institutions in Soviet Successor States. New York: Cambridge University Press.

Mahdavi, Paasha. (2011) State Ownership and the Resource Curse: A New Dataset on Nationalizations in the Oil Industry. Available at http://ssrn.com/abstract=1916590.

Mahdavy, Hossein. (1970) The Patterns and Problems of Economic Development in Rentier States: The Case of Iran. In Studies in Economic History of the Middle East, edited by M. A. Cook. London: Oxford University Press.

Manzano, Osmel, and Francisco Monaldi. (2008) The Political Economy of Oil Production in Latin America. Economía 9(1):59 98.

Marcel, Valérie, and John V. Mitchell. (2006) Oil Titans: National Oil Companies in the Middle East. Washington, DC: Brookings Institution Press.

McPherson, Charles, and Stephen MacSearraigh. (2007) Corruption in the Petroleum Sector. In Many Faces of Corruption: Tracking Vulnerabilities at the Sector Level, edited by J. Edgardo Campos and Sanjay Pradhan. Washington, DC: World Bank.

Mommer, Bernard. (2002) Global Oil and the Nation State. New York: Oxford University Press.

Morrison, Kevin. (2008) Oil, Nontax Revenue, and the Redistributional Foundations of Regime Stability. International Organization 63:107 138.

Oyefusi, Aderoju. (2007) Oil and the Propensity to Armed Struggle in the Niger Delta Region of Nigeria. World Bank Policy Research Working Paper 4194.

Oyefusi, Aderoju. (2010) Oil, Youths, and Civil Unrest in Nigeria's Delta: The Role of Schooling, Educational Attainments, Earnings, and Unemployment. Conflict Management and Peace Science 27(4):326 346.

Quinn, John J. (2008) The Effect of Majority State Ownership of Significant Economic Sectors on Corruption: A Cross Regional Comparison. International Interactions 34:84 128.

Ray, James L. (2003) Explaining Interstate Conflict and War: What Should Be Controlled for? Conflict Management and Peace Science 20(2):1 31.

Rodrik, Dani. (1997) Has Globalization Gone Too Far? Washington, DC: Institute for International Economics.

Ross, Michael L. (2003) Oil, Drugs, and Diamonds: How Do Natural Resources Vary in Their Impact on Civil War? In Beyond Greed and Grievance: The Political Economy of Armed Conflict, edited by Kareb Ballentine and Jake Sherman. Boulder: Lynne Rienner. 
Ross, Michael L. (2004) How Do Natural Resources Influence Civil War? Evidence from 13 Cases. International Organization 58:35 67.

Ross, Michael L. (2006) A Closer Look at Oil, Diamonds, and Civil War. Annual Review of Political Science 9:265 300.

Ross, Michael L. (2012) The Oil Curse: How Petroleum Wealth Shapes the Development of Nations. Princeton, NJ: Princeton University Press.

Rudra, Nita, and Stephan Haggard. (2005) Globalization, Democracy, and Effective Welfare Spending in the Developing World. Comparative Political Studies 38(9):1015 1049.

Smith, Benjamin. (2004). Oil Wealth and Regime Survival in the Developing World, 1960 1999. American Journal of Political Science 48(2):232 246.

Snyder, Richard, and Ravi Bhavnani. (2005) Diamonds, Blood, and Taxes: A Revenue Centered Framework for Explaining Political Order. Journal of Conflict Resolution 49 (4):563 597.

Sorens, Jason. (2011) Mineral production, territory, and ethnic rebellion: The role of rebel constituencies. Journal of Peace Research 48(5):571 585.

Stevens, Paul. (2008) National Oil Companies and International Oil Companies in the Middle East: Under the Shadow of Government and the Resource Nationalism Cycle. Journal of World Energy Law \& Business 1(1):5 30.

Taydas, Zeynep, and Dursun Peksen. (2012) Can states buy peace? Social welfare spending and civil conflicts. Journal of Peace Research 49(2):273 287.

Thies, Cameron. (2010) Of Rulers, Rebels, and Revenue: State Capacity, Civil War Onset, and Primary Commodities. Journal of Peace Research 47(3):321 332.

Wegenast, Tim. (2013) Opening Pandora's Box? Inclusive Institutions and the Onset of Internal Conflict in Oil Rich Countries. International Political Science Review 34(4):392 410.

Wegenast, Tim, and Matthias Basedau. (2014) Ethnicity, Natural Resources and Civil War. Conflict Management and Peace Science 31(4):432 457. 


\section{Appendix}

Table A1. Hydrocarbon Ownership Structure of All Countries within the Sample (Averages over the Period 1989-2010).

\begin{tabular}{|c|c|c|c|c|c|c|}
\hline Country & $\begin{array}{l}\text { Share of } \\
\text { Government } \\
\text { Production } \\
\text { (in \%) }\end{array}$ & $\begin{array}{l}\text { Share of } \\
\text { Domestic } \\
\text { Private } \\
\text { Production } \\
\text { (in \%) }\end{array}$ & $\begin{array}{l}\text { Share of } \\
\text { Foreign } \\
\text { Private } \\
\text { Production } \\
\text { (in \%) }\end{array}$ & $\begin{array}{c}\text { Per Capita } \\
\text { Government } \\
\text { Production (in } \\
\text { Thousand Barrels } \\
\text { of Oil Equivalent } \\
\text { per Day) }\end{array}$ & $\begin{array}{c}\text { Per Capita } \\
\text { Private } \\
\text { Production (in } \\
\text { Thousand Barrels } \\
\text { of Oil Equivalent } \\
\text { per Day) }\end{array}$ & $\begin{array}{c}\text { Number } \\
\text { of Civil } \\
\text { War } \\
\text { Onsets } \\
(1989 \\
2010)\end{array}$ \\
\hline Algeria & 94 & 0 & 6 & 0.0863 & 0.0053 & 1 \\
\hline Angola & 41 & 0 & 45 & 0.0340 & 0.0392 & 8 \\
\hline Argentina & 20 & 13 & 49 & 0.0054 & 0.0221 & 0 \\
\hline Australia & 0 & 41 & 45 & 0 & 0.0517 & 0 \\
\hline Azerbaijan & 74 & 0 & 11 & 0.0345 & 0.0080 & 4 \\
\hline Bahrain & 100 & 0 & 0 & 0.2539 & 0 & 0 \\
\hline Brazil & 54 & 52 & 0.8 & 0.0036 & 0.0041 & 0 \\
\hline Brunei & 47 & 0 & 49 & 0.5415 & 0.5611 & 0 \\
\hline Cameroon & 65 & 0 & 34 & 0.0048 & 0.0025 & 0 \\
\hline Canada & 6 & 30 & 26 & 0.0083 & 0.1010 & 0 \\
\hline China & 75 & 17 & 3 & 0.0023 & 0.0006 & 0 \\
\hline Colombia & 57 & 1 & 24 & 0.0100 & 0.0043 & 0 \\
\hline Congo & 0 & 0 & 86 & 0 & 0.0615 & 3 \\
\hline Ecuador & 65 & 0 & 14 & 0.0218 & 0.0048 & 0 \\
\hline Egypt & 45 & 0 & 35 & 0.0085 & 0.0067 & 1 \\
\hline $\begin{array}{c}\text { Equatorial } \\
\text { Guinea }\end{array}$ & 5 & 0 & 71 & 0.0247 & 0.2686 & 0 \\
\hline Gabon & 11 & 0 & 74 & 0.0326 & 0.2037 & 0 \\
\hline Iran & 100 & 0 & 0 & 0.0715 & 0 & 7 \\
\hline Iraq & 100 & 0 & 0 & 0.0756 & 0 & 3 \\
\hline Kuwait & 100 & 0 & 0 & 1.1149 & 0 & 0 \\
\hline Libya & 56 & 0 & 18 & 0.1884 & 0.0565 & 0 \\
\hline Malaysia & 66 & 0 & 28 & 0.0405 & 0.0173 & 0 \\
\hline Mexico & 100 & 0 & 0 & 0.0404 & 0 & 2 \\
\hline Nigeria & 58 & 2 & 34 & 0.0113 & 0.0071 & 2 \\
\hline Norway & 56 & 8 & 33 & 0.4572 & 0.3330 & 0 \\
\hline Oman & 54 & 36 & 30 & 0.2291 & 0.2790 & 0 \\
\hline Qatar & 90 & 0 & 0 & 1.6846 & 0 & 0 \\
\hline Russia & 46 & 46 & 2 & 0.0561 & 0.0532 & 5 \\
\hline Saudi Arabia & 94 & 0 & 0 & 0.4594 & 0 & 0 \\
\hline Sudan & 100 & 0 & 0 & 0.0048 & 0 & 0 \\
\hline $\begin{array}{l}\text { Trinidad and } \\
\text { Tobago }\end{array}$ & 25 & 0 & 74 & 0.0654 & 0.2931 & 1 \\
\hline Tunisia & 45 & 0 & 39 & 0.0054 & 0.0046 & 0 \\
\hline Turkmenistan & 100 & 0 & 0 & 0.2195 & 0 & 0 \\
\hline $\begin{array}{c}\text { United Arab } \\
\text { Emirates }\end{array}$ & 77 & 0 & 3 & 0.8387 & 0.0385 & 0 \\
\hline Venezuela & 99 & 0 & 3 & 0.1394 & 0.0043 & 1 \\
\hline
\end{tabular}

Note. Only cases in which the sum of state-owned, privately domestic-owned and privately foreign-owned hydrocarbons made up for more than $65 \%$ of the country's total oil and gas production were considered. For this reason, the following five countries have been excluded from the table: Bolivia, Indonesia, Kazakhstan, Syria, and Vietnam. 
Table A2. Variable Definitions and Data Sources.

\begin{tabular}{|c|c|c|}
\hline Variable & Definition & Source \\
\hline $\begin{array}{l}\text { Minor civil war } \\
\text { onset }\end{array}$ & $\begin{array}{l}\text { Intrastate conflict onset. } 1 \text { if there is a } \\
\text { conflict onset with more than } 25 \text { annual } \\
\text { battle-related deaths; } 0 \text { otherwise }\end{array}$ & $\begin{array}{l}\text { UCDP/PRIO Armed Conflict Dataset, } \\
\text { version } 4 / 2012 \text { (Gleditsch et al., } \\
\text { 2002) }\end{array}$ \\
\hline $\begin{array}{l}\text { Ethnic } \\
\text { fractionalization }\end{array}$ & $\begin{array}{l}\text { Herfindahl index measuring the probability } \\
\text { that two randomly selected individuals } \\
\text { from the entire population will be from } \\
\text { different ethnic groups. Only politically } \\
\text { relevant ethnic groups are considered. }\end{array}$ & $\begin{array}{l}\text { Cederman, Minn, and Wimmer } \\
\text { (2010) }\end{array}$ \\
\hline Population (log) & Population, log-transformed & $\begin{array}{l}\text { Penn World Tables (Heston et al. } \\
\text { 2009) }\end{array}$ \\
\hline GDPPC & PPP converted GDP per capita & $\begin{array}{l}\text { Penn World Tables (Heston et al. } \\
\text { 2009) }\end{array}$ \\
\hline Instability & $\begin{array}{l}\text { Political instability: number of years since } \\
\text { an institutional change that led to a } \\
\text { minimum of } 3 \text { points' change on the Polity } \\
\text { index }\end{array}$ & Polity IV Project (Version 2010) \\
\hline gdpgrowth & Annual change in GDP, percent & World Development Indicators \\
\hline mixed regime & $\begin{array}{l}\text { Dummy variable that equals } 1 \text { when a } \\
\text { country ranges in the middle of the Polity } \\
\text { index }(5 \text { to }+5)\end{array}$ & Polity IV Project (Version 2010) \\
\hline Welfare spending & $\begin{array}{l}\text { Welfare spending (education, health and } \\
\text { social security) as a percentage of GDP }\end{array}$ & Taydas and Peksen (2012) \\
\hline Elections & $\begin{array}{l}\text { Dummy variable that equals } 1 \text { if a country } \\
\text { has held legislative or executive elections } \\
\text { in a given year }\end{array}$ & $\begin{array}{l}\text { Database of Political Institutions } \\
\text { (DPI) }\end{array}$ \\
\hline Inflation & $\begin{array}{l}\text { Inflation measured by the annual growth } \\
\text { rate of the GDP implicit deflator, showing } \\
\text { the rate of price change in the economy as } \\
\text { a whole. }\end{array}$ & World Development Indicators \\
\hline Left party & $\begin{array}{l}\text { Largest government party is a left-wing } \\
\text { party }\end{array}$ & Database of Political Institutions \\
\hline Trade openness & $\begin{array}{l}\text { Sum of total exports and imports divided } \\
\text { by the GDP in constant prices }\end{array}$ & $\begin{array}{l}\text { Penn World Tables (Heston et al. } \\
\text { 2009) }\end{array}$ \\
\hline pc total prod & Per capita total production of oil and gas & OGOS data set \\
\hline gdp total prod & $\begin{array}{l}\text { Total production of oil and gas as a } \\
\text { percentage of GDP }\end{array}$ & OGOS data set \\
\hline pc priv prod & $\begin{array}{l}\text { Per capita production of oil and gas by } \\
\text { private companies }\end{array}$ & OGOS data set \\
\hline pc gov prod & $\begin{array}{l}\text { Per capita production of oil and gas by } \\
\text { state companies }\end{array}$ & OGOS data set \\
\hline gdp priv prod & $\begin{array}{l}\text { Total production of oil and gas by private } \\
\text { companies as a percentage of GDP }\end{array}$ & OGOS dataset \\
\hline gdp gov prod & $\begin{array}{l}\text { Total production of oil and gas by state } \\
\text { companies as a percentage of GDP }\end{array}$ & OGOS data set \\
\hline
\end{tabular}

